A Preliminary, Full Spectrum, Magnetic Anomaly Grid of the United States with Improved Long Wavelengths for Studying Continental Dynamics: A Website for Distribution of Data

Open-File Report 2009-1258 


\section{A Preliminary, Full Spectrum, Magnetic Anomaly Grid of the United States with Improved Long Wavelengths for Studying Continental Dynamics: A Website for Distribution of Data}

By D. Ravat, C. Finn, P. Hill, R. Kucks, J. Phillips, R. Blakely, C. Bouligand, T. Sabaka, A. Elshayat, A. Aref, and E. Elawadi

Open-File Report 2009-1258 


\section{U.S. Department of the Interior \\ KEN SALAZAR, Secretary \\ U.S. Geological Survey \\ Marcia K. McNutt, Director}

U.S. Geological Survey, Reston, Virginia: 2009

This and other USGS information products are available at http://store.usgs.gov/
U.S. Geological Survey
Box 25286, Denver Federal Center
Denver, CO 80225
To learn about the USGS and its information products visit http://www.usgs.gov/
1-888-ASK-USGS

Any use of trade, product, or firm names is for descriptive purposes only and does not imply endorsement by the U.S. Government.

Although this report is in the public domain, permission must be secured from the individual copyright owners to reproduce any copyrighted materials contained within this report.

Suggested citation:

Ravat, D., Finn, C., Hill, P., Kucks, R., Phillips, J., Blakely, R., Bouligand, C., Sabaka, T., Elshayat, A., Aref, A., and Elawadi, E., 2009, A preliminary, full spectrum, magnetic anomaly grid of the United States with improved long wavelengths for studying continental dynamics--A website for distribution of data: U.S. Geological Survey Open-File Report 2009-1258, 2 p. 
Contents

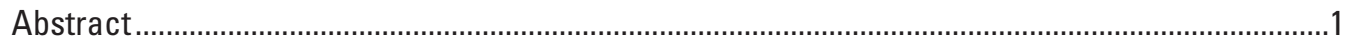

Full Spectrum Magnetic Anomaly Map...................................................................................... 2 


\title{
A Preliminary, Full Spectrum, Magnetic Anomaly Grid of the United States with Improved Long Wavelengths for Studying Continental Dynamics: A Website for Distribution of Data
}

\author{
By D. Ravat' ${ }^{1}$ C. Finn², P. Hill², R. Kucks², J. Phillips², R. Blakely ${ }^{3}$, C. Bouligand ${ }^{3}$, T. Sabaka ${ }^{4}$, A. Elshayat ${ }^{5}$, \\ A. Aref ${ }^{5}$, and E. Elawadi ${ }^{5}$ \\ ${ }^{1}$ University of Kentucky (Lexington, Kentucky) \\ ${ }^{2}$ United States Geological Survey (Denver, Colorado) \\ ${ }^{3}$ United States Geological Survey (Menlo Park, California) \\ ${ }^{4}$ Raytheon/NASA-GSFC (Greenbelt, Maryland) \\ ${ }^{5}$ Nuclear Materials Authority (Cairo, Egypt)
}

\section{Abstract}

Under an initiative started by Thomas G. Hildenbrand of the U.S. Geological Survey, we have improved the longwavelength $(50-2,500 \mathrm{~km})$ content of the regional magnetic anomaly compilation for the conterminous United States by utilizing a nearly homogeneous set of National Uranium Resource Evaluation (NURE) magnetic surveys flown from 1975 to 1981 . The surveys were flown in quadrangles of $2^{\circ}$ of longitude by $1^{\circ}$ of latitude with east-west flight lines spaced 4.8 to $9.6 \mathrm{~km}$ apart, north-south tie lines variably spaced, and a nominal terrain clearance of $122 \mathrm{~m}$. Many of the surveys used base-station magnetometers to remove external field variations.

The NURE surveys were originally processed with International Geomagnetic Reference Field (IGRF)/Definitive Geomagnetic Reference Field (DGRF) core-field models, which left behind nonuniform residual trends in the data and discontinuities at survey boundaries. In this study, in place of the IGRF/DGRF models, we used a spatially and temporally continuous model of the magnetic field known as the Comprehensive Model (CM), which allowed us to avoid discontinuities at survey boundaries. The CM simultaneously models the core magnetic field and long-wavelength ionospheric and magnetospheric fields, along with their induced components in the earth. Because of the availability of basestations for removing external fields, we removed only the core-derived geomagnetic field based on the present version of the model, CM4 (spherical harmonic degree 13) for our compilation.

The NURE data have short-wavelength (less than $30 \mathrm{~km}$ ) noise due to cultural sources, base-station offsets, and residual external field effects. It is possible to reduce and even remove these defects by identifying and editing them and by applying leveling and micro-leveling. There are also many highresolution, individual surveys over the U.S. which could be incorporated into the improved NURE database; however, this could take a few years. Therefore, we have created a preliminary, full spectrum, $1.25-\mathrm{km}$ magnetic anomaly grid from a database by combining short-wavelength magnetic anomalies from the North American Magnetic Anomaly Map (NAMAM) and long-wavelength anomalies from NURE using a Gaussian filter centered at $50-\mathrm{km}$ wavelength. We call this product the NURE-NAMAM2008 magnetic database and grid. NURENAMAM2008 is useful for analyzing geodynamic aspects of the crustal and mantle magnetic field that require precise long-wavelength information; for example, estimating Curietemperature depths and constraining estimates of lithospheric temperatures. Preliminary studies show that the corrected long-wavelength components in NURE-NAMAM2008 lead to more realistic Curie depths for the average western U.S. crust. The grid and a format explanation file accompany this abstract. An image of the grid with North American boundaries is included with this report. 


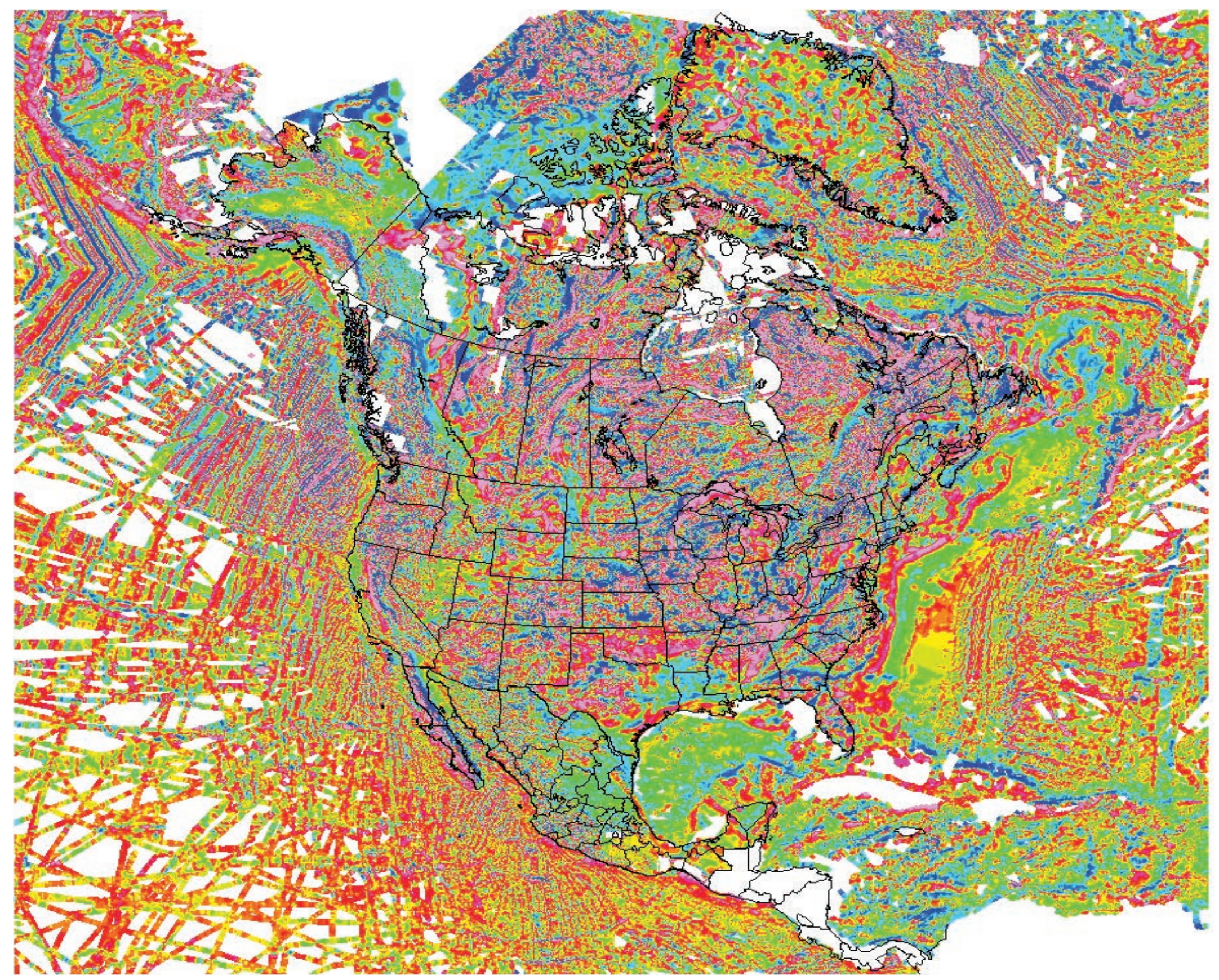


